\title{
PP - Organic synthesis of uracil from interstellar organic molecules
}

\author{
Jorge Enrique Bueno Prieto \\ Universidad Nacional de Colombia, Faculty of Science, Department of Biology, Colombia \\ email: jebuenop@unal.edu.co
}

\begin{abstract}
It is important to say that the formaldehyde and hydrogen cyanide have been detected in the interstellar medium through resonance spectrum emission. Here I describe a way to produce uracil in interstellar space.
\end{abstract}

Keywords. Uracil, synthesis, RNA

\section{Introduction}

Different theories adopt RNA as the first molecule that could be catalyzed and replicated to begin life. At present one of its components, ribose, acts as a screen that reflects dangerous rays, and therefore it is possible to maintain constant integrity of the molecule. However, at the same time different inserts of ribonucleotides result in mutations that in large quantities could produce variations in the production of enzymes and proteins that later made it easy to initiate new ways of life. Other important components are: phosphates, adenine, guanine, citocine, and uracil.

Uracil is a pyrimidine which is common and naturally occurring. Found in RNA, it base pairs with adenine and is replaced by thymine in DNA. Methylation of uracil produces thymine. It turns into thymine to protect the DNA and to improve the efficiency of DNA replication. Uracil can base pair with any of the bases depending on how the molecule arranges itself on the helix, but readily pairs with adenine because the methyl group is repelled into a fixed position.

\section{Theoretical proposal}

The synthesis of uracil is proposed from two molecules of hydrogen cyanide plus formaldehyde, to get malononitrile, from which occurs malonamide. A mediator can generate 3-amino-3-hidroxypropenamide that, through a functional group exchange, generates a chloride of 3-oxoprofenol, which generates uracil by the addition of urea (in industrial production).

\section{Acknowledgements}

We thank the IAU 251 Committee for travel support and Airline AVIANCA, and Mary Ruth Garcia Conde, a teacher of the National University of Colombia.

\section{References}

Bada, J. L. \& Lazcano, A. 2002, Science, 296, 1982

Bailey, J. M. 1997, Biochem. Soc. Trans., 25, S651

Brosius, J. 2001, Trends Biochem. Sci., 26, 653 
Gilbert, W. 1986, Nature, 319, 618

Janas, T. \& Yarus, M. 2003, RNAPubl. RNA Soc., 9, 1353

Jan, E., Kinzy, T. G., \& Sarnow, P. 2003, Proc. Natl. Acad. Sci., USA 100, 15, 410

Lyons, A. J. \& Robertson, H. D. 2003, J. Biol. Chem., 278, 26844

Miller, S. L. 1998, in: Brack, A. (ed.), The endogenous synthesis of organic compounds, The Molecular Origins of Life, (Cambridge University Press, Cambridge), p. 59

Orgel, L. E. 2004, Critical Rev. Biochem. Molec. Biol., 39, 99

Schmidt, J. G., Nielsen, P. E., \& Orgel, L. E. 1997,Nucleic Acids Res., 25, 4797

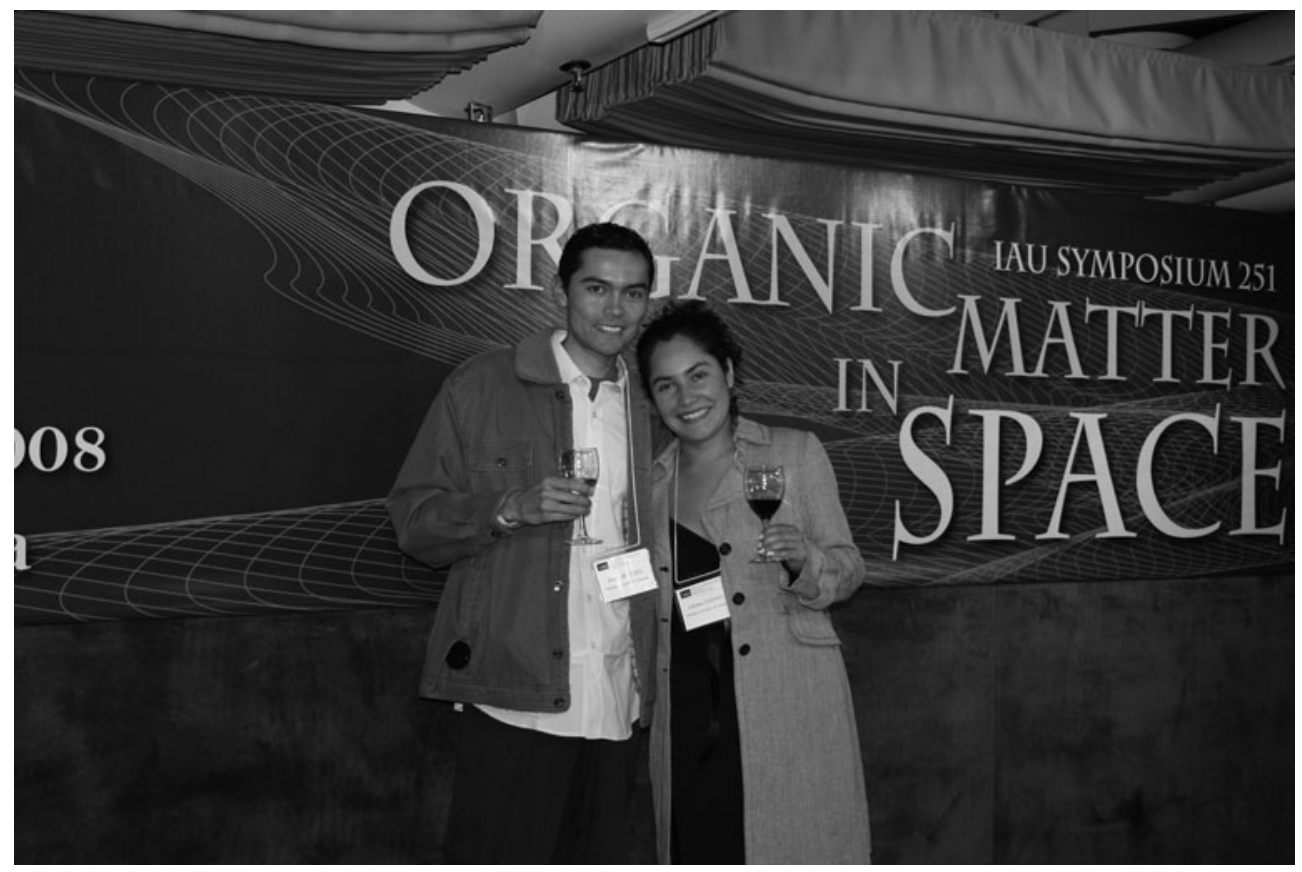

Jorge Enrique Bueno Prieto and Adriana Patricia Lozano Medellin during the welcome reception at Renaissance Harbour View Hotel 